\title{
Learning From Presentation Bagi Mahasiswa Berkebutuhan Khusus Tuna Grahita Jurusan Pendidikan Guru Sekolah Dasar
}

\author{
Agus Kichi Hermansyah $^{1}$, Nurlayli Hasanah ${ }^{2}$, Dewi Puji Rahyu ${ }^{3}$ \\ Program studi PGSD, Fakultas Keguruan dan Ilmu Pendidikan, Universitas \\ Musamus, Indonesia ${ }^{1,3}$ \\ Jurusan Pendidikan Guru Pendidikan Anak Usia Dini, Fakultas Keguruan dan Ilmu \\ Pendidikan, Universitas Musamus, Indonesia ${ }^{2}$ \\ aguskichi@unmus.ac.id
}

\begin{abstract}
Abstrak
Penelitian ini bertujuan untuk mendeskripsikan penerapan learning from presentation dalam pembelajaran mahasiswa berkebutuhan khusus tuna grahita yang terdapat di Jurusan Pendidikan Guru Sekolah Dasar, Universitas Musamus. Berdasarkan hasil asesmen, terdapat 1 mahasiswa berkebutuhan khusus yakni tuna grahita. Jenis penelitian yang digunakan yaitu penelitian deskriptif dengan pendekatan kualitataif. Penelitian ini disebut deskriptif karena menghasilkan data studi kasus berupa gambaran mengenai penerapan learning from presentation dalam pembelajaran mahasiswa tuna grahita. Teknik pengumpulan data menggunakan observasi berperan serta, wawancara mendalam, dan dokumentasi. Teknik analisis data dalam penelitian ini menggunakan teknik analisis data kualitatif meliputi reduksi data, penyajian data, dan penarikan kesimpulan. Hasil penelitian menunjukkan bahwa presentasi tidak hanya dipakai oleh mahasiswa tuna grahita, tetapi juga dipakai oleh mahasiswa normal. Perbedaan penerapan presentasi untuk mahasiswa tuna grahita membutuhkan tambahan waktu. Kegiatan evaluasi menggunakan teknik lisan. Mahasiswa tuna grahita bisa menjelaskan materi presentasi di depan kelas walaupun dengan kata-kata yang terpenggal-penggal.
\end{abstract}

Kata kunci: learning from presentation; tuna grahita; PGSD 


\section{PENDAHULUAN}

Setiap anak memiliki hak untuk mengembangkan kemampuan yang ada pada dirinya melalui pendidikan. Hal tersebut sesuai dengan Undang-Undang No. 20 Tahun 2003 mengenai sistem pendidikan nasional. Cara berpikir setiap anak berbeda karena faktor bawaan lahir dan faktor intelektual (Puspita, 2019), (Hermansyah, Suyono, \& Hasanah, 2017). Pendidikan tersebut juga berhak diperoleh bagi anak berkebutuhan khusus (ABK). ABK yakni individu yang memiliki perbedaan karakteristik dengan individu pada umumnya. ABK memerlukan perlakuan khusus sesuai kebutuhan dengan kategori yang dialaminya (Sari, Binahayati \& Muhammad, 2017). Anak berkebutuhan khusus berhak memperoleh pendidikan seperti anak normal lainnya. Penyelenggaraan pendidikan untuk ABK tidak serta merta hanya bisa dilakukan di sekolah khusus. Lembaga-lembaga pendidikan pada umumnya harus bisa mengakomodir anak-anak dengan kebutuhan khusus. ABK harus ditingkatkan kualitasnya agar menjadi subjek pembangunan (Fauzie \& Herawati, 2014).

ABK tidak hanya dijumpai di tingkat sekolah. Tingkat perguruan tinggi juga tidak luput dari adanya anak berkebutuhan khusus. Hal ini merupakan bukti bahwa ABK juga bisa mengenyam pendidikan pada tingkat yang tinggi. ABK bukan berarti anak yang tidak memiliki kemampuan apapun. ABK tidak selalu dikategorikan anak yang memiliki cacat atau kekurangan seaca fisik. Apabila dikategorikan, ABK dapat dikategorikan menurut Desiningrum (2016) yakni: (1) gangguan kemampuan kecerdasan atau belajar meliputi, slow learner, cerdas istimewa berbakat istimewa, tuna grahita, berkesulitan belajar, (2) gangguan kepribadian, diantaranya tuna laras, indigo, autisme, ADHD, dan kecemasan, dan (3) gangguan jasmani, diantaranya tunarungu, tunadaksa, tunanetra, dan tunaganda.

Pemahaman dosen dalam mengenali jenis ABK di kelasnya akan mempermudah dosen dalam pemilihan metode pembelajaran yang sesuai, sehingga mampu mengakomodir pembelajaran untuk mahasiswa dengan kemampuan normal dan khusus. Jenis anak berkebutuhan yang sering dijumpai di lembaga pendidikan normal yakni tuna grahita. Mahasiswa tuna grahita yakni mahasiswa yang mempunyai kemampuan di bawah rata-rata, mempunyai hambatan dalam berinteraksi dan mememfokuskan perhatian (Saputri, Ningsih \& Widyawati, 2017). 
Mahasiswa yang menyandang tuna grahita memiliki sedikit kemampuan kecerdasan. Tuna grahita memiliki kemampuan di bawah mahasiswa yang normal (Afiffah \& Soendari, 2017). Pembelajaran bagi mahasiswa tuna grahita bermaksud mengembangkan potensinya secara optimal (Hidayah, Sujadi \& Pangadi, 2014). Penggunaan model pembelajaran yang sesuai akan mampu mengakomodir mahasiswa tuna grahita dalam proses pembelajaran. Mahasiswa tuna grahita memiliki IQ di bawah IQ mahasiswa yang normal (Indrawati, 2016).

Permasalahan yang menjadi faktor penyebab mahasiswa tuna grahita di antaranya yakni lemahnya kemampuan intelektual dan ketidakcakapan sosial (Sunusi, Soetjiningsih dan Kristijanto 2018). Mahasiswa tuna grahita mengalami kesulitan saat berinteraksi sosial dan sulit dalam memfokuskan perhatian (Saputri, Ningsih \& Widyawati, (2017). Oleh karena itu, tingkat kepercayaan diri mahasiswa tuna grahita rendah karena merasa memiliki kemampuan intelektual yang rendah, tuna grahita lebih memilih berteman dengan teman yang memiliki umur lebih kecil darinya sehingga jumlah tuna grahita terbatas jumlah teman sebayanya. Mahasiswa tuna grahita harus dapat menyelesaikan tugas yang dibebankan oleh setiap mata kuliah dengan segala keterbatasan.

Metode dan penilaian yang dilakukan dosen dalam pembelajaran hendaknya dapat diterima oleh seluruh mahasiswa, termasuk di dalamnya yakni mahasiswa tuna grahita. Sekalipun mahasiswa tuna grahita memiliki kemampuan mengingat, tetapi tidak semua stimulus disimpan dalam ingatannya, bergantung pada besarnya fokus yang diberikan oleh mahasiswa terhadap stimulus yang diberikan. Dengan demikian, model pembelajaran diharapkan dapat mengakomodir keterbatasan mahasiswa dalam penerapannya di dalam kelas. Salah satu model pembelajaran yang dapat diterapkan dalam pembelajaran yang melibatkan mahasiswa tuna grahita ialah pembelajaran Learning from Presentation.

Penggunaan model pembelajaran yang dipakai hendaknya mampu mengakomodir mahasiswa tuna grahita. Sehingga, pembelajaran dengan menerapkan model pembelajaran Learning from Presentation diharapkan dapat membantu mahasiswa tuna grahita dalam menghadapi masalah yang terjadi dirinya. Model pembelajaran ini yaitu aktivitas berbicara atau mengemukakan pendapat di depan 
orang banyak (Pranayoga, 2013). Kegiatan presentasi dapat dipakai oleh mahasiswa tuna grahita dalam mengatasi rasa kurang percaya dirinya.

\section{METODE PENELITIAN}

Penelitian ini merupakan penelitian deskriptif memakai pendekatan kualitatif. Penelitian ini tergolong penelitian deskriptif sebab memiliki output data studi kasus yakni gambaran mengenai metode pembelajaran Learning from Presentation di Jurusan Pendidikan Guru Sekolah Dasar, Fakultas Keguruan dan Ilmu Pendidikan, Universitas Musamus yang memiliki mahasiswa dengan berkebutuhan khusus. Tempat tersebut dipilih sebab merupakan tempat mengajar peneliti. Subjek yang diteliti yang digunakan sebagai informan yakni Dosen pengampu mata kuliah Pendidikan Anak Berkebutuhan Khusus dan mahasiswa tuna grahita.

Objek penelitian yakni metode pembelajaran Learning from Presentation yang digunakan oleh dosen pengampu mata kuliah untuk mengajar mahasiswa tuna grahita. Teknik pengumpulan data meliputi observasi berperan serta, wawancara mendalam dan dokumentasi. Data diukur keabsahannya dengan memakai triangulasi teknik dan sumber. Analisis data memakai teknik analisis data kualitatif. Analisis data meliputi kegiatan reduksi data, penyajian data dan penarikan kesimpulan.

\section{HASIL DAN PEMBAHASAN}

Dosen pengampu mata kuliah memakai metode pembelajaran Learning from Presentation dilengkapi dengan metode tanya jawab, ceramah, diskusi dan penugasan. Metode pembelajaran yang dominan dipakai oleh dosen pengampu mata kuliah yakni metode presentasi (Learning from Presentation). Mahasiswa tuna grahita diberikan kesempatan di depan kelas untuk mempresentasikan materi tentang jenis-jenis anak berkebutuhan khusus bersama teman kelompoknya. Mahasiswa tuna grahita mendapat porsi lebih sedikit untuk menjelaskan materi tentang jenis-jenis anak berkebutuhan khusus.

Pembagian kelompok presentasi tidak memandang perbedaan pada mahasiswa, antara mahasiswa tuna grahita dan mahasiswa normal. Berdasarkan wawancara dengan dosen pengampu mata kuliah, hal tersebut dilaksanakan dengan tujuan agar mahasiswa tuna grahita tidak merasa dibedakan dengan mahasiswa normal lainnya. Pembagian kelompok tanpa membedakan mahasiswa tuna grahita dengan mahasiswa normal juga bertujuan agar mahasiswa yang berkemampuan normal tidak 
memandang berbeda mahasiswa tuna grahita. Hingga pada akhirnya situasi kelas akan tetap kondusif tanpa adanya kelompok-kelompok mahasiswa yang nantinya membuat mahasiswa tuna grahita menjadi merasa dibedakan di dalam kelas.

Pembagian porsi mahasiswa tuna grahita untuk mempresentasikan materi disesuaikan dengan kemampuan mahasiswa dalam menyampaikan materi. Mahasiswa tuna grahita mampu menyampaikan materi presentasi, hanya saja membutuhkan waktu yang lebih banyak dari mahasiswa lainnya. Penampilan mahasiswa tuna grahita saat menjelaskan materi presentasi di depan kelas terlihat kurang percaya diri.

Hal tersebut terlihat dari tatapan mata yang tidak fokus terhadap mahasiswa yang lain, mahasiswa cenderung menatap ke bawah. Mahasiswa tuna grahita memiliki ekspresi yang datar ketika mempresentasikan materi. Ekspresi muka selalu sama dari awal sampai berkahirnya kegiatan presentasi. Dosen pengampu mata kuliah membantu mahasiswa tuna grahita saat kegiatan presentasi berlangsung. Pada Gambar 1 dapat dilihat bahwa dosen memberikan bantuan kepada mahasiswa ABK dalam menyampaikan materi pembelajaran di depan kelas.

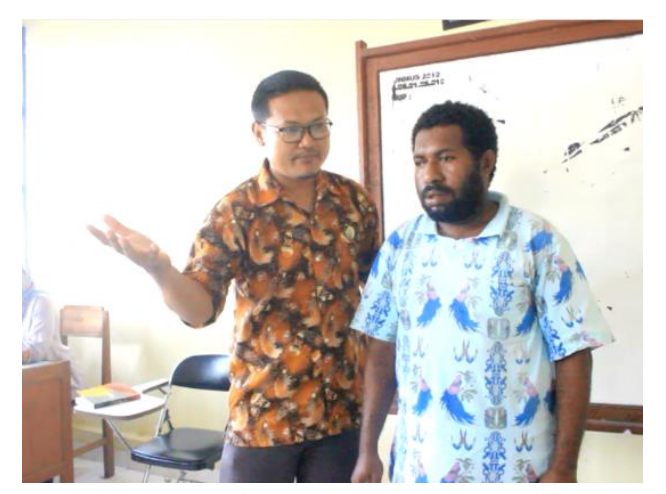

Gambar 1. Dosen membimbing mahasiswa tuna grahita saat proses presentasi

Pada Gambar 1, nampak mahasiswa tuna grahita pada saat presentasi terlihat terbata-bata saat memaparkan materi presentasi. Pengulangan kata selalu dilakukan oleh mahasiswa tuna grahita hampir di semua kata yang diucapkan ketika presentasi. Setiap kalimat yang diucapkan oleh mahasiswa tuna grahita selalu ada kata yang terpenggal-penggal, seperti je.. je... nis... je... nis... a... nak.. ber.. ke... bu.. tuh... an... khu... khu.. sus... begitu seterusnya. Mahasiswa tuna grahita membutuhkan waktu yang lebih lama untuk mempresentasikan materi. Hal tersebut karena saat 
pemaparan materi, mahasiswa tersebut terbata-bata. Terjadi pengulangan disetiap kata yang diucapkan oleh mahasiswa tuna grahita. Hal tersebut membuat waktu yang dipakai oleh mahasiswa tuna grahita dalam mempresentasikan materi menjadi lebih lama.

Mahasiswa tuna grahita belum mampu menanggapi pertanyaan teman ketika diskusi berlangsung. Hal tersebut terlihat dari intensitas mahasiswa tuna grahita menjawab pertanyaan saat kegiatan diskusi presentasi berlangsung. Mahasiswa tuna grahita tidak pernah menjawab pertanyaan teman ketika proses presentasi berlangsung. Mahasiswa lebih banyak diam dan memiliki tatapan kosong kepada mahasiswa lain yang sedang terlibat diskusi.

Bedasarkan hasil observasi, dosen pengampu mata kuliah sangat memfasilitasi dan memotivasi mahasiswa tuna grahita. Hal tersebut dilakukan dengan memberikan kesempatan kepada mahasiswa untuk mempresentasikan materi, sekali pun dengan keterbatasan yang dimiliki. Hal tersebut dengan tujuan agar mahasiswa tuna grahita memiliki kepercayaan diri di depan umum dan mampu memahami materi yang disampaikan. Hal tersebut bermanfaat bagi mahasiswa, sehingga nantinya mahasiswa tuna grahita mampu untuk bersaing dengan mahasiswa normal lainnya.

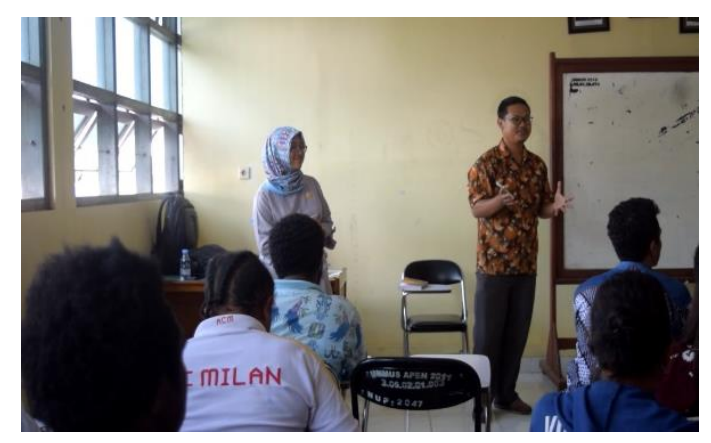

Gambar 2. Dosen memotivasi mahasiswa

Gambar 2. Dosen pengampu mata kuliah memberikan motivasi kepada mahasiswa yang di dalamnya terdapat ABK dalam mengikuti pembelajaran. Dosen pengampu mata kuliah pula memberikan kesempatan kepada mahasiswa tuna grahita untuk menjawab pertanyaan teman terkait materi yang telah disampaikan. Dalam menjawab pertanyaan mahasiswa, mahasiswa tuna grahita membutuhkan waktu yang lama untuk menjawab pertanyaan tersebut, meskipun demikian dosen pengampu mata kuliah tetap dengan sabar menunggu mahasiswa tersebut selesai untuk 
mengemukakan jawabannya. Kemudian, nampak terlihat dosen pengampu mata kuliah, menanyakan kepada mahasiswa yang lain apakah mahasiswa tuna grahita sudah tepat menyampaikan jawabannya walaupun dengan kata-kata yang terbatabata dan dengan durasi waktu yang lebih lama.

Dosen pengampu mata kuliah mampu mengorganisir jalannya presentasi. Hal tersebut terlihat dari terjadinya komunikasi aktif saat proses presentasi dan diskusi materi berlangsung. Pembelajaran dengan melibatkan mahasiswa tuna grahita perlu ekstra keahlian dalam mengelola pembelajaran. Dengan demikian pembelajaran dapat berlangsung dengan baik. Dosen pengampu mata kuliah pula mampu mengatur jalannya pembelajaran, sehingga semua mahasiswa mampu memperhatikan dan memahami materi perkuliahan. Ketika mahasiswa tuna grahita memperoleh kesempatan untuk menjawab pertanyaan, dosen memandu mahasiswa tuna grahita dengan menjelaskan kembali maksud dari pertanyaan yang diajukan oleh temannya.

Mahasiswa tuna grahita perlu bimbingan lebih saat menjawab pertanyaan teman saat diskusi. Hal tersebut dikarenakan mahasiswa tuna grahita belum memahami sepenuhnya maksud pertanyaan yang diajukan oleh temannya. Dosen perlu menjelaskan kembali maksud dari pertanyaan tersebut, dengan tujuan agar mahasiswa tuna grahita mampu menjawab dengan baik pertanyaan temannya serta menumbuhkan kepercayaan diri pada mahasiswa tuna grahita karena ia mampu menanggapi pertanyaan temannya.

Mahasiswa tuna grahita lebih memilih diam daripada mengikuti jalannya diskusi ketika kegiatan presentasi berlangsung. Mahasiswa tuna grahita hanya akan menjawab pertanyaan yang ditujukan kepada dirinya. Mahasiswa tuna grahita belum memiliki inisiatif untuk menjawab pertanyaan temannya yang diajukan untuk kelompoknya. Keaktifan tuna grahita hanya ditunjukkan melalui kegiatan presentasi materi yang telah dibebankan kepadanya. Lebih dari itu, tidak tampak muncul inisiatif dari mahasiswa tuna grahita untuk berbuat lebih aktif dalam kegiatan presentasi.

Mahasiswa tuna grahita cenderung pasif ketika kegiatan diskusi berlangsung. Sikap pasif mahasiswa tuna grahita ditunjukkan oleh mahasiswa tuna grahita dari tidak adanya inisitif untuk menjawab pertanyaan teman terkait materi yang dipresentasikan. Mahasiswa tuna grahita hanya menjawab pertanyaan ketika 
pertanyaan tersebut ditujukan kepada dirinya. Hal tersebut berbeda dengan mahasiswa normal yang terlihat sangat aktif untuk menjawab pertanyaan teman.

Mahasiswa tuna grahita dan mahasiswa normal mempunyai peran yang sama dalam kegiatan pembelajaran. Berdasarkan pemaparan dosen pengampu mata kuliah bahwa dengan menerapkan metode presentasi, dosen mengharapkan agar mahasiswa tuna grahita memperoleh pembelajaran dari teman kelompoknya (tutor sebaya) sehingga akan memperkuat hubungan antar mahasiswa di dalam kelas. Seorang mahasiswa yang bisa membantu mahasiswa lain di dalam kelas akan menciptakan suasana kelas yang menyenangkan dan lebih sehat. Contohnya mahasiswa yang pandai, bisa membantu mahasiswa yang memiliki kesulitan, khususnya mahasiswa tuna grahita.

Kegiatan tutor sebaya tidak diartikan memberikan jawaban atau mahasiswa tuna grahita hanya mengikuti jawaban yang disampaikan oleh teman sebayanya. Tujuan dilakukannya tutor sebaya yakni agar mahasiswa tuna grahita lebih mudah memahami materi dengan diberi tambahan penjelasan oleh mahasiswa lainnya. Kegiatan pembelajaran dengan adanya satu mahasiswa tuna grahita tidak ada perbedaan. Dosen pengampu mata kuliah memperlakukan sama antara mahasiswa penyandang tuna grahita dan mahasiswa normal lainnya. Pada saat presentasi, mahasiswa diberikan kesempatan untuk memaparkan materi presentasi. Jika mahasiswa tuna grahita sudah agak lama terdiam karena bingung mau apa yang mau disampaikan, dosen pengampu membangkitkan kembali motivasi anak tuna grahita dengan melemparkan pertanyaan-pertanyaan sebagai umpan agar mahasiswa tuna grahita mampu melanjutkan kembali presentasinya.

Pemberian pertanyaan kepada anak tunagrahita selalu difasilitasi oleh dosen pengampu mata kuliah dengan memberikan umpan jawaban agar mahasiswa tuna grahita dapat menjawab pertanyaan yang disampaikan oleh mahasiswa lainnya. Kegiatan tersebut dilakukan dengan tujuan agar mahasiswa tunagrahita tetap percaya diri di dalam kelas, ketika kegiatan presentasi berlangsung. Kegiatan evaluasi dilakukan pada akhir pembelajaran. Kegiatan evaluasi untuk mahasiswa tuna grahita dilakukan sama dengan mahasiswa normal lainnya. Evaluasi dilakukan dengan teknik tes berbentuk tes lisan. Tes lisan dipilih dengan tujuan agar mahasiswa berkemampuan normal maupun mahasiswa penyandang tuna grahita tetap bisa 
melaksanakan kegiatan evaluasi tanpa merasa terdiskrimasi (dapat dilihat pada Gambar 3).

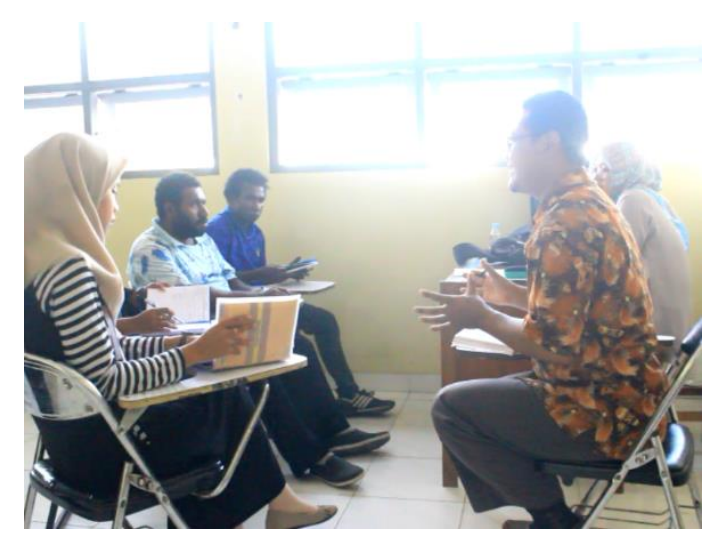

Gambar 3. Dosen Memberikan Evaluasi Lisan

Dosen pengampu mata kuliah memberikan tambahan waktu kepada mahasiswa tuna grahita untuk menjawab soal evaluasi. Pada saat evaluasi lisan, dosen memancing mahasiswa tuna grahita agar mampu menjawab evaluasi secara lisan seperti yang dapat dilihat pada Gambar 4. Gambar tersebut menunjukkan bahwa dosen pengampu mata kuliah memberikan waktu yang lebih kepada mahasiswa ABK untuk menjawab pertanyaan.

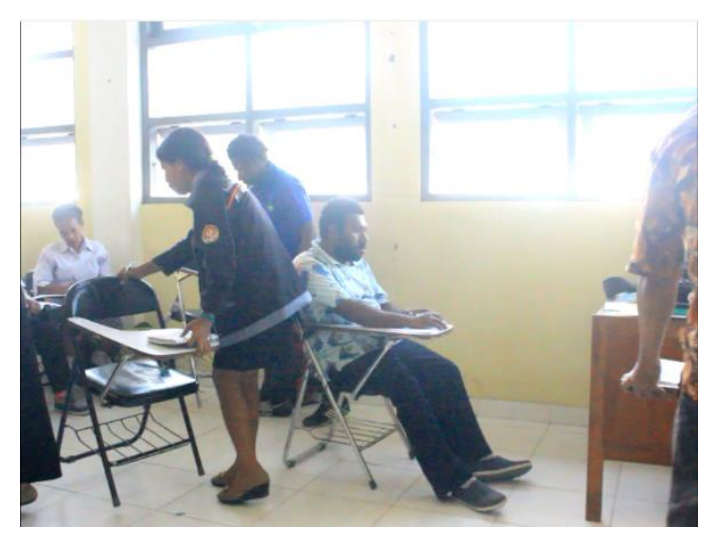

Gambar 4. Dosen memberikan tambahan waktu kepada mahasiswa tuna grahita untuk menjawab evaluasi secara lisan

\section{SIMPULAN}

Learning from Presentation atau yang dikenal pembelajaran dengan menggunakan presentasi dapat digunakan dalam pembelajaran untuk mengakomodir mahasiswa normal dan mahasiswa penyandang tuna grahita. Pelaksanaan presentasi dalam pembelajaran yang dilakukan oleh mahasiswa tuna grahita memerlukan waktu 
yang lebih lama karena mahasiswa tuna grahita masih terbata-bata saat menyampaikan materi presentasi.

Tutor sebaya diperlukan untuk lebih memantapkan kemampuan anak tuna grahita dalam memahami materi pembelajaran. Tutor sebaya juga berguna agar suasana di dalam kelas lebih hidup tanapa adanya diskriminasi antara mahasiswa berkemampuan normal dengan mahasiswa penyandang tuna grahita. Kegiatan evaluasi menggunakan teknik lisan mampu mengakomodir mahasiswa penyandang tuna grahita dan mahasiswa berkemampuan normal. Pada pelaksanaannya dosen pengampu mata kuliah memberikan waktu yang lebih kepada mahasiswa tuna grahita untuk menjawab soal evaluasi secara lisan dibandingkan mahasiswa dengan kemampuan normal.

\section{DAFTAR PUSTAKA}

Afiffah, N., \& Soendari, T. (2017). Meningkatkan Kemampuan Berbicara pada Anak Tuna Grahita Sedang Melalui Media Gambar di SLB B-C YPLAB Kota Bandung. JASSI_anakku, Volume 18 Nomor 1.

Desiningrum, D. R. (2016). Psikologi Anak Berkebutuhan Khusus. Yogyakarta: Psikosain.

Fauzie, M. M. \& Herawati, L. (2014). Pengaruh Penyuluhan Terhadap Peningkatan Motivasi dan Tindakan dalam Mencuci Tangan dan Membuang Sampah Pada Anak Penyandang Tuna Grahita di Sleman. Jurnal Kesehatan Lingkungan, Volume 5 Nomor 4.

Hermansyah, A. K., Suyono, S., \& Hasanah, M. (2017). Desain Pembelajaran Berbicara Untuk Mengenalkan Nilai-Nilai Moral Kemanusiaan Melalui Bermain Peran. Jurnal Edukasi, 4(1), 38-42.

Hidayah, Sujadi \& Pangadi. (2014). Proses Berpikir Tuna Grahita Ringan Dalam Memecahkan Masalah Matematika Bentuk Soal Certa Pasa Operasi Hitung Campuran. Jurnal of Mathematics and Mathematics Education, Volume 4 Nomor 1.

Indrawati, T. (2016). Pelaksanaan Pembelajaran Anak Tuna Grahita. Jurnal Pendidikan Guru Sekolah Dasar, Edisi 14.

Pranayoga, B. N. (2013). Implementasi Metode Diskusi dan Presentasi Dalam Upaya Meningkatkan Partisipasi Aktif Siswa Pada Mta Pelajaran Kopling Kelas XI SMK Muhammadiyah 4 Klaten Tengah. Skripsi: UNY.

Puspita, Z. (2019). Pengaruh Model Pembelajaran Auditory Intellektuali Refetition Terhadap Berfikir Kreatif Dan Hasil Belajar Mahasiswa Semester Ganjil 
Pada Mata Kuliah Inovasi Pendidikan. Jurnal DIDIKA: Wahana Ilmiah Pendidikan Dasar, 4(1), 47-55.

Saputri, S., Ningsih, E. F. \& Widyawati, S. (2017). Analisis Kesulitan Anak Tuna Grahita Dalam Menyelesaikan Soal Operasi Penjumlahan Di Sekolah Luar Biasa (SLB) Harapan Ibu Metro. Mapan: Jurnal Matematika dan Pembelajaran, Volume 5 Nomor 2.

Sari, S. M F., Binahayati \& Muhammad, T. (2017). Pendidikan Bagi Anak Tuna Grahita. Jurnal Penelitian \& PKM, Volume 4 Nomor 2.

Sunusi, H. C., Soetjiningsih, C. H. \& Kristijanto, A. I. (2018). Picture Exchange Communication Systems (PECS) dan Communication Apprehension (CA) pada Remaja Tuna Grahita Jenjang SD di SLBN Salatiga. Jurnal Psikologi, Volume 45 Nomor 2. 